\title{
PERLINDUNGAN PULAU-PULAU TERLUAR INDONESIA BERDASARKAN KONSEP NEGARA KEPULAUAN
}

\author{
Yeheschiel Bartin Marewa, Edgar Michael Parinussa \\ Universitas Kristen Indonesia Paulus, ybmarewa@gmail.com
}

\begin{abstract}
Abstrak
Negara Kesatuan Republik Indonesia merupakan negara kepulauan yang dengan jumlah pulau terbesar di dunia dan memiliki kekayaan yang berlimpah, tak terkecuali yang terkandung dalam pulau-pulau terluarnya. Meskipun demikian, ternyata Pemerintah Indonesia belum sepenuhnya memberdayakan dan mengelola pulau-pulau terluar secara optimal. Penelitian ini bertujuan menganalisis perlindungan pulau-pulau terluar Indonesia berdasarkan konsep negara kepulauan. Penelitian ini menggunakan metode normatif yuridis dengan pendekatan konseptual. Hasil penelitian menunjukkan bahwa keberadaan pulau-pulau terluar di Indonesia telah mendapatkan pengakuan secara internasional berdasarkan United Nations Convention on The Law of the Sea 1982 melalui penggunaan garis pangkal lurus kepulauan. Perlindungan terhadap pulau-pulau terluar tersebut dilakukan dalam bentuk kebijakan negara melalui peraturan perundang-undangan dan berbagai tindakan pengelolaan.

Kata Kunci : Pulau-Pulau Terluar; Negara Kepulauan
\end{abstract}

\section{Abstract}

The Unitary State of the Republic of Indonesia is an archipelagic country with the largest number of islands in the world and has abundant wealth, including those contained in the outer islands. However, it turns out that the Indonesian government has not fully empowered and managed the outer islands optimally. This study aims to analyze the protection of Indonesia's outer islands based on the concept of an archipelago state.The results show that the existence of the outer islands in Indonesia has received international recognition based on the United Nations Convention on The Law of the Sea 1982 through the use of archipelago baseline. Protection of the outer islands is carried out in the form of state policies through statutory regulations and any management actions.

Keywords : Outer Islands; Archipelago State

\section{Pendahuluan}

Perjuangan Indonesia sejak Deklarasi Djuanda tahun 1957 membuahkan hasil dengan diakuinya konsepsi Archipelago State dalam United Nations Convention on The Law of the Sea (UNCLOS) 1982 sekaligus menetapkan Archipelagic Baseline atau Garis Pangkal Kepulauan. Dalam UNCLOS, ketentuan mengenai Negara Kepulauan terdapat dalam Bab IV, mulai Pasal 46 hingga Pasal 54. Di dalam Bab tersebut, terdapat tiga istilah yang menjadi ciri khas negara kepulauan, yaitu Garis Pangkal Kepulauan, Perairan Kepulauan, dan Alur Laut Kepulauan. UNCLOS 1982 mengatur bahwa negara kepulauan merupakan negara yang terdiri atas satu atau lebih gugusan pulau, di mana diantaranya terdapat pulau-pulau lain yang merupakan satu kesatuan politik atau secara historis merupakan satu ikatan.

Secara geografis, Indonesia merupakan negara kepulauan terbesar di dunia, yang terdiri dari 17.504 pulau, di mana terdapat 5 pulau besar, yaitu Jawa dengan luas $132.107 \mathrm{~km}^{2}$, Sumatra dengan luas $473.606 \mathrm{~km}^{2}$, Kalimantan dengan luas 
$539.460 \mathrm{~km}^{2}$, Sulawesi dengan luas $189.216 \mathrm{~km}^{2}$, dan Papua dengan luas $421.981 \mathrm{~km}^{2}$. Wilayah Indonesia terbentang sepanjang 3.977 mil di antara Samudra Hindia dan Samudra Pasifik. Luas daratan Indonesia adalah $1.922 .570 \mathrm{~km}^{2}$ dan luas perairannya $3.257 .483 \mathrm{~km}^{2} .{ }^{1}$ Tidak dapat dipungkiri bahwa belasan ribu pulau yang terhampar dari Sabang hingga Merauke, Miangas hingga Pulau Rote memiliki potensi sumber daya alam yang sangat besar. Namun, keberadaan pulau tersebut, khsusunya pulau-pulau terluar yang berbatasan dengan negara lain belum mendapatkan perhatian secara serius. Dari belasan ribu pulau yang dimiliki Indonesia, terdapat 92 pulau terluar yang tersebar di wilayah NKRI dengan luas masing-masing pulau ratarata 0,02 hingga 200 kilometer persegi, dan hanya 50\% dari pulau terluar tersebut yang berpenghuni. ${ }^{2}$

Meskipun UNCLOS 1982 telah menjadi dasar bagi penetapan wilayah laut suatu negara, namun polemik mengenai perbatasan negara Indonesia dengan negara lain masih sering terjadi. Hal ini dapat berdampak pada status kepemilikan pulaupulau terluat Indonesia yang berbatasan dengan negara lain. Bahkan wilayah perbatasan Indonesia cenderung dipermainkan oleh negara tetangga karena tidak jelasnya garis tapal batas. Terkadang, Indonesia tidak bisa berbuat banyak ketika menghadapi masalah terkait perbatasan, khususnya yang terkait dengan pulau-pulau terluar karena banyak di antara pulau terluar tersebut yang belum terdaftar dan belum ditentukan tapal batasnya oleh pemerintah. ${ }^{3}$ Dalam persoalan pencaplokan pulau terluar misalnya, Indonesia harus belajar dari kasus lepasnya Pulau Sipadan dan Ligitan dari pangkuan Ibu Pertiwi sebagai akibat dari pembiaran dan tidak terurusnya wilayah tersebut.

Terkait dengan pulau-pulau terluar, pada dasarnya terdapat beberapa persoalan yang patut menjadi perhatian, yaitu Pertama, letak pulau-pulau terluar yang sangat jauh dari kontrol pemerintah dan rawan dicaplok oleh negara lain. Kedua, banyak diantara pulau tersebut yang tercancam hilang, terutama akibat abrasi yang berpotensi mengurangi wilayah Indonesia, khususnya di wilayah perbatasan. Selain itu, banyak pula pulau yang tidak terdaftar dalam lembaran negara. Ketiga, banyak di antara pulau terluar yang tidak berpenduduk, sehingga sangat rentan terhadap pendudukan atau penguasaan negara lain. Keempat, tidak adanya program yang dapat meningkatkan kehidupan menyarakat yang menempati pulau-pulau tersebut, dan cenderung memilih untuk berinteraksi dengan masyarakat dari negara tetangga. ${ }^{4}$ Sebagi contoh, kondisi di Pulau Sebatik yang merupakan salah satu pulau terluar

\footnotetext{
${ }^{1}$ https://id.wikipedia.org/wiki/Indonesia\#Geografi

${ }^{2}$ Ayub Torri Satriyo Kusumo, (2010), Optimalisasi Pengelolaan dan Pemberdayaan Pulau-Pulau Terluar Dalam Rangka Mempertahankan Keutuhan Negara Kesatuan Republik Indonesia, Jurnal Dinamika Hukum, v10n3, hal. 328

3 Fadjri Alihar, (2018), Kebijakan Pengelolaan Pulau-Pulau Terluar Ditinjau Dari Aspek Kependudukan, Jurnal Kebijakan Sosel KP, v8n1, hal. 40

4 Ibid
} 
Indoensia, yang kondisinya sangat kontras jika dibandingkan dengan Tawau, Sabah, Malaysia. Tawau merupakan pusat perdagangan yang sangat maju di Sabah, sementara kondisi Pulau Sebatik layaknya daerah tertinggal, padahal kaya akan sumberdaya alam. Namun dalam kenyataannya semua hasil bumi dari Pulau Sebatik mengalir ke Tawau untuk diolah menjadi komoditi perdagangan.

Pada dasarnya, kebijakan strategis dan langkah-langkah operasional dalam mempertahankan eksistensi pulau-pulau terluar dapat dilakukan dengan pengimplementasian Pasal 46 dan Pasal 47 UNCLOS 1982 yang mengatur tentang Archipelagic State dan Archipelagic Base Line. 5 Pentingnya perlindungan terhadap pulau-pulau terluar saat ini dilakukan, mengingat hal tersebut terkait dengan berbagai isu strategis wilayah perbatasan, yaitu aspek batas wilayah negara, aspek ekonomi, aspek sosial budaya, aspek pertahanan dan keamanan, aspek sumber daya alam dan lingkungan, dan aspek kelembagaan dan capacity building.

Pulau-pulau terluar bila dikelola dengan baik akan berdampak positif bagi pengembangan ekonomi kawasan perbatasan serta menjaga berbagai potensi yang ada. Kondisi ini ternyaa kontraproduktif dengan kondisi yang ada di lapangan, dimana pulau-pulau terluar masih dibiarkan kosong tanpa penghuni dan pengawasan ekstra dari pemerintah. Berdasarkan latar belakang tersebut, penelitian ini akan menganalisis tanggung jawab negara dalam melindungi pulau-pulau terluar Indonesia dan sekaligus melihat kendala yang dihadapi oleh pemerintah Indonesia dalam melindungi pulau-pulau terluar.

\section{Metode}

Penulisan artikel ini menggunakan metode penelitian hukum dengan pendekatan yuridis normatif dengan mengacu pada norma-norma hukum internasional. Data yang digunakan dalam artikel ini adalah data sekunder berupa bahan hukum primer yaitu norma hukum internasional yaitu Konvensi Hukum Laut 1982 dan Peraturan Perundang-Undang terkait dengan wilayah Indonesia. Selain itu, digunakan juga bahan hukum sekunder yaitu literatur berupa buku, jurnal, dan artikel terkait. Analisis data dalam artikel ini menggunakan analisis kualitatif dengan mendeskripsikan fakta-fakta yang ada, kemudian dilakukan analisis berdasarkan norma hukum internasiona maupun teori yang ada.

\section{Konsep Wilayah Negara}

Secara umum, wilayah merupakan sebuah daerah yang dikuasai atau menjadi teritorial dari sebuah kedaulatan. Suatu wilayah biasanya dikelilingi oleh batas-batas kondisi alam, seperti gunung, sungai, dan laut. Pada masa setelah kolonialisme, batas-

\footnotetext{
${ }^{5}$ Bambang Susanto, (2004), Kajian Yuridis Permasalahan Batas Maritim Wilayah Laut Republik Indonesia (Suatu Pandangan TNI AL Bagi Pengamanan Batas Wilayah Laut RI), Indonesian Journal of International Law, Special Edition, Desember, hal. 46
} 
batas tersebut dibuat oleh negara yang menduduki suatu wilayah, dan berikutnya dengan adanya negara bangsa, istilah yang lebih umum digunakan adalah batas nasional. Wilayah dalam sebuah negara dapat dibatasi berdasarkan kondisi fisik alam yang ada dan juga dapat dibatasi oleh tembok yang dibuat oleh pemerintah negara yang berdaulat.

Menurut Rebecca M.Wallace, wilayah negara merupakan atribut yang nyata dari kenegaraan dan dalam wilayah geografis tertentu yang ditempatnya, suatu negara menikmati dan melaksanakan kedaulatan. ${ }^{6}$ Dalam Ensiklopedia Umum, yang dimaksud dengan wilayah negara adalah bagian muka bumi daerah tempat tinggal, tempat hidup dan sumber hidup warga negara dari negara tersebut. Pasal 1 angka 1 Undang-undang Nomor 43 Tahun 2008 tentang Wilayah Negara mendefinisikan wilayah negara sebagai salah satu unsur negara yang merupakan satu kesatuan wilayah daratan, perairan pedalaman, perairan kepulauan dan laut teritorial beserta dasar laut dan tanah di bawahnya, serta ruang udara di atasnya, termasuk seluruh sumber kekayaan yang terkandung di dalamnya. I Wayan Parthiana menyatakan bahwa wilayah negara meliputi :

a. Wilayah daratan termasuk tanah didalamnya, yang merupakan tempat pemukiman atau kediaman dari warga negara atau penduduk negara yang bersangkutan. Termasuk pula dalam ruang lingkup wilayah daratan ini tidak saja permukaan tanah daratan, tetapi juga tanah di bawah daratan tersebut.

b. Wilayah perairan yang merupakan bagian perairan yang merupakan wilayah suatu negara

c. Wilayah dasar laut dan tanah di bawahnya yang terletak di bawah wilayah perairan, yang meliputi juga dasar laut dan tanah di bawahnya yang terletak di bawah wilayah perairan, sehingga negara memiliki kedaulatan terhadap dasar laut dan tanah di bawahnya, segala sumber daya alam yang terkandung di dalamnya adalah menjadi hak dan kedaulatan sepenuhnya dari negara yang bersangkutan.

d. Wilayah ruang udara yang merupakan bagian wilayah negara adalah ruang udara yang terletak di atas permukaan wilayah daratan dan di atas permukaan wilayah perairan. $^{7}$

Pasal 1 Konvensi Motevideo 1933 menyatakan bahwa "The state as a person of international law should possess the following qualifications: (a) a permanent population; (b) a defined territory; (c) government; and (d) capacity to enter into relations with the other states". Berdasarkan aturan tersebut, terdapat syarat konstitutif berdirinya sebuah negara, yaitu adanya wilayah yang tetap (permanent territory) yang merupakan unsur mutlak yang harus ada. Wilayah merupakan suatu ruang sebagai tempat bagi orang menjadi warga negara atau penduduk untuk dapat hidup dan menjalankan

\footnotetext{
${ }^{6}$ Rebecca M. Wallace, (1993), Hukum Internasional, IKIP Semarang Press, Semarang, hal. 95

${ }^{7}$ I Wayan Parthiana, (1990), Pengantar Hukum Internasional, Mandar Maju, Bandung, hal. 103
} 
aktifitasnya. Dalam sejarah kehidupan umat manusia atau negara-negara, terkadang timbul konflik yang disebabkan oleh masalah wilayah yang antara lain bisa disebabkan karena keinginan untuk melakukan ekspansi wilayah atau karena memang tidak jelasnya garis batas wilayah antara dua atau lebih negara.

Menurut Oppenheim tanpa adanya wilayah dengan batas-batas tertentu suatu negara tidak dapat dianggap sebagai subjek hukum internasional. ${ }^{8}$ Pengertian negara disini tidak dapat dipisahkan dari konsep dasar negara sebagai suatu kesatuan geografis disertai dengan kedaulatan dan yurisdiksinya masing-masing. Oleh karena itu, wilayah negara merupakan konsep yang sangat mendasar dan fundamental dalam hukum internasional, untuk menunjukkan adanya kekuasaan tertinggi dan eksklusif negara dalam batas-batas wilayahnya. ${ }^{9}$ Urgensi keberadaan wilayah negara tercermin dalam prinsip penghormatan terhadap integritas kewilayahan (territorial integrity) yang mana hal tersebut termuat dalam berbagai instrumen hukum internasional.

Berdasarkan prinsip tersebut, kemudian muncul adanya prinsip kedaulatan dan non intervensi terhadap permasalahan internal suatu negara. Kedaulatan negara sendiri merupakan konsep penting dalam hukum internasional dan telah melahirkan berbagai ketentuan hukum tentang perolehan dan hilangnya wilayah negara. Esensi dari kedaulatan teritorial terletak pada kondisi faktual maupun legal sehingga suatu wilayah dapat dianggap berada dibawah kedaulatan suatu negara tertentu. Kedaulatan yang dimiliki oleh negara mengandung pengertian bahwa terdapat halhal yang berhubungan dengan tanggung jawab negara terhadap wilayahnya. Dalam hal ini, negara menyelenggarakan yurisdiksinya atas masyarakat, segala kebendaan dan kegiatan lain dalam wilayahnya atau yang disebut juga dengan kedaulatan teritorial.

Menurut Jawahir Thontowi dan Pranoto Iskandar, kedaulatan atas wilayah merupakan kewenangan yang dimiliki oleh suatu negara untuk melaksanakan kewenangannya dalam batas wilayah-wilayah yang telah menjadi bagian dari kekuasaannya. ${ }^{10}$ Terkait dengan kedaulatan teritorial, Sugeng Istanto menyebutkan salah satu kualifikasi yang harus dipenuhi negara sebagai subjek hukum internasional adalah wilayah tertentu, di mana negara sebagai organisasi kekuasaan menguasai wilayah tersebut. Di wilayah itu negara memegang kekuasaan kenegaraan yang tertinggi, yakni hak melakukan kedaulatan wilayah. Dalam wilayah itu negara tersebut melaksanakan fungsi kenegaraan dengan mengecualikan negara lain. ${ }^{11}$

\footnotetext{
${ }^{8}$ Mochtar Kusumaatmadja dan Agoes, E. R. (2010). Pengantar Hukum Internasional. P.T. Alumni, Bandung, hal. 161

${ }^{9}$ Ibid, hal. 161-162

10 Jawahir Thontowi dan Pranoto Iskandar, (2006), Hukum Internasional Kontemporer, PT.Refika Aditama, Bandung, hal.169

${ }^{11}$ F. Sugeng Istanto, (1994), Hukum Internasional, Penerbitan Universitas Atma Jaya, Yogyakarta, hal.33
} 
Kedaulatan teritorial negara dalam suatu wilayah dibatasi oleh kedaulatan yang dimiliki oleh negara lain terhadap wilayahnya, yang mana hal ini ditandai dengan batas wilayah yang merupakan pemisah unit regional geografi yang dikuasai oleh suatu negara.

\section{Konsep Negara Kepulauan}

\subsection{Negara Kepulauan Dalam UNCLOS 1982}

Konsepsi Negara Kepulauan adalah suatu konsepsi baru dalam hukum laut internasional yang mendapat pengakuan dalam Konvensi 1982. Seperti diketahui, pada masa sebelum lahirnya Konvensi 1982, konsepsi Negara Kepulauan dikenal hanya melalui praktik beberapa negara, yang paling menonjol diantaranya adalah Indonesia. Konsepsi mengenai negara kepulauan telah dituangkan dalam beberapa asas yaitu asas-asas negara kepulauan (archipelagic states principles) dan tercantum dalam Bab IV United Nations Convention on The Law of the Sea (UNCLOS) 1982 yang terdiri dari sembilan pasal, yaitu Pasal 46 hingga Pasal 54. Pada pengaturan tersebut berisi ketentuan mengenai negara kepulauan, garis pangkal kepulauan, status hukum dari perairan kepulauan, penetapan perairan pedalaman dalam perairan kepulauan, hak lintas damai melalui perairan kepulauan, hak lintas alur laut kepulauan, hak dan kewajiban kapal dan pesawat udara asing dalam pelaksanaan hak lintas alur-alur laut kepulauan. ${ }^{12}$ Berdasarkan Pasal 46 butir (a), disebutkan bahwa negara kepulauan berarti suatu Negara yang seluruhnya terdiri dari satu atau lebih kepulauan dan dapat mencakup pulau-pulau lain. Sedangkan pengertian kepulauan dalam Pasal 46 butir (b) berarti suatu gugusan pulau, termasuk bagian pulau, perairan diantaranya dan lain-lain wujud alamiah yang hubungannya satu sama lainnya demikian eratnya sehingga pulau-pulau, perairan dan wujud alamiah lainnya itu merupakan suatu kesatuan geografi, ekonomi dan politik yang hakiki, atau yang secara historis diangap sebagai demikian.

Pengaturan dalam Bab IV UNCLOS 1982 memberikan ketentuan mengenai negara kepulauan (archipelagic states), di mana UNCLOS 1982 memberikan dasar pengaturan dalam bentuk definisi negara kepulauan yang memiliki perbedaan dengan negara yang secara geografis wilayahnya berbentuk kepulauan. Dalam Pasal 46 memberikan perbedaan pengertian secara yuridis antara negara kepulauan dengan kepulauan itu sendiri. ${ }^{13}$ Perbedaan ini menimbulkan konsekuensi bahwa penarikan garis pangkal lurus kepulauan (straight archipelagic baseline) tidak bisa dilakukan oleh semua negara yang mengatasnamakan dirinya sebagai negara kepulauan. Hal ini dikarenakan ada beberapa syarat yang harus dipenuhi bila ingin melakukan

\footnotetext{
12 Etty. R. Agoes, (2004), Praktik Negara-Negara Atas Konsepsi Negara Kepulauan, Jurnal Hukum Internasional, v1n3, hal. 443

${ }^{13}$ Sigit Sutadi Nugroho, (2019), Implementasi Ketentuan Pasal 50 UNCLOS di Wilayah Negara Kepulauan, Junal Rechtsvinding, v8n2, hal. 297
} 
penarikan garis pangkal lurus kepulauan, yaitu satu kesatuan geografis, ekonomi, politik, dan historis. ${ }^{14}$

Pengakuan konsepsi Negara Kepulauan sangat penting karena hal tersebut sangat berkaitan dengan cara penetapan zona maritim. Dalam hal ini, terdapat perbedaan tata cara penetapan zona maritim antara negara kepulauan dengan negara pantai. Penentuan zona maritim pada Negara Kepulauan menggunakan garis pangkal lurus kepulauan sebagaimana diatur dalam Pasal 46 sampai Pasal 54 UNCLOS 1982 mengenai persyaratan obyektif penarikan garis pangkal lurus kepulauan. UNCLOS 1982 mengatur bahwa setiap negara kepulauan dapat menarik garis pangkal kepulauan yang menghubungkan titik-titik terluar pulau-pulau dan karang kering terluar dari kepulauan. Panjang garis yang demikian maksimal adalah 100 mil laut dan 3 persen dari jumlah seluruh garis pangkal yang ada dapat melebihi kepanjangan tersebut, hingga maksimal 125 mil laut.

Berdasarkan Pasal 47 UNCLOS 1982, penggunaa garis pangkal kepulauan harus memenuhi empat syarat, yaitu :

a. Seluruh daratan utama dari negara yang bersangkutan harus menjadi bagian dari sistem garis pangkal kepulauan;

b. perbandingan antara luas perairan dan daratan di dalam sistem garis pangkal harus berkisar antara 1:1 dan 9:1;

c. panjang segmen garis pangkal kepulauan tidak boleh melebihi 100 mil laut, kecuali hingga 3 persen dari keseluruhan jumlah garis pangkal meliputi suatu negara kepulauan boleh melebihi 100 mil laut hingga panjang maksimum 125 mil laut;

d. arah garis pangkal kepulauan yang ditentukan tidak boleh menjauh dari konfigurasi umum kepulauan.

Kedaulatan negara di wilayah tersebut meliputi pula ruang udara di atas perairan kepulauan, tanah dibawahnya serta kekayaan yang terkandung didalamnya.

Di dalam perairan kepulauan, negara kepulauan dapat menarik garis-garis penutup untuk keperluan penetapan batas perairan pedalamannya, bagi mulut sungai, teluk dan pelabuhan. ${ }^{15}$ Selanjutnya, dalam Pasal 48 diatur bahwa ketentuan dalam Pasal 47 merupakan garis pangkal untuk pengukuran lebar Laut Teritorial, Zona Tambahan, Zona Ekonomi Eksklusif dan Landas Kontinen bagi suatu negara kepulauan. Dengan kata lain, Pasal 48 mengukuhkan bahwa pada suatu negara kepulauan, garis-garis pangkal lurus kepulauan mempunyai fungsi yang sama dengan garis-garis pangkal lain yang diakui oleh UNCLOS 1982, seperti garis-garis pangkal biasa dan garis-garis pangkal lurus. ${ }^{16}$

Berbeda halnya dengan akibat penarikan garis-garis pangkal biasa maupun garis-garis pangkal lurus dimana status hukum dari perairan yang tertutup oleh garis

\footnotetext{
${ }^{14}$ Maskun, Konsepsi Negara Kepulauan, dalam www.negarahukum.com

${ }^{15}$ Sigit Sutadi Nugroho, Loc.cit, hal. 297

${ }^{16}$ Maskun, Op.cit
} 
pangkal menjadi perairan pedalaman, dalam penarikan garis-garis pangkal lurus kepulauan perairan yang tertutup oleh garis-garis pangkal tersebut akan memiliki status hukum sebagai perairan kepulauan. ${ }^{17}$ Meskipun terletak pada sisi dalam dari garis-garis pangkal lurus kepulauan, status hukum perairan kepulauan berbeda dengan perairan pedalaman. UNCLOS 1982 telah memberikan pengakuan terhadap penggunaan garis pangkal kepulauan dalam menentukan batas perairan. Akan tetapi tidak serta merta mengakibatkan negara kepulauan tidak boleh menggunakan garis pangkal normal ataupun garis pangkal lurus. Suatu negara kepulauan selain menerapkan garis pangkal kepulauan juga dapat menggunakan garis pangkal normal maupun garis pangkal lurus dalam pengukuran lebar laur teritorialnya.

Terkait dengan status hukum tersebut, prinsip negara kepulauan diterima sebagai suatu paket, dimana pada satu sisi, negara-negara lain mengakui kedaulatan penuh negara kepulauan atas perairan kepulauan, dasar laut dan tanah di bawahnya, serta ruang udara di atas perairan kepulauan. Di sisi lain, negara kepulauan menghormati hak-hak yang dimiliki negara lain di perairan kepulauan. ${ }^{18}$ Hak-hak negara lain di perairan kepulauan seperti halnya kapal dari semua negara dapat menikmati hak lintas damai yang melalui perairan kepulauan dan semua kapal serta pesawat udaha dapat menikmati hak lintas alur laut kepulauan sesuai dengan alur laut dan rute penerbangan. Dengan kata lain, pada perairan kepulauan, kedaulatan negara dibatasi dengan kewajiban untuk mengakomodasikan kepentingan masyarakat internasional.

\subsection{Indonesia Sebagai Negara Kepulauan}

Indonesia merupakan negara kepulauan terbesar di dunia yang secara geografis terletak pada posisi strategis, yaitu berada di antara dua benua yakni Benua Asia dan Benua Australia, dan dua samudera yakni Samudera Hindia dan Samudera Pasifik. Secara geografis sebagai negara kepulauan, dua pertiga wilayah Indonesia berupa lautan yaitu 6,32 juta kilometer persegi dan terdiri dari 17.504 pulau-pulau. Kondisi geografis ini juga menempatkan Indonesia sebagai negara yang memiliki garis pantai terpanjang kedua di dunia setelah Kanada yaitu 99.093 kilometer persegi. ${ }^{19}$

Eksistensi Indonesia sebagai negara kepulauan juga telah ditetapkan dalam Pasal 25 Undang-Undang Dasar Negara Republik Indonesia Tahun 1945 yang menyatakan bahwa Negara Kesatuan Republik Indonesia adalah negara kepulauan yang berciri nusantara dengan wilayah yang batas-batas dan ha-haknya ditetapkan dengan Undang-Undang. Deklarasi Juanda yang memuat konsep Negara Kepulauan yang dituangkan dalam Peraturan Pemerintah Pengganti Undang-Undang dan

\footnotetext{
${ }^{17}$ Etty. R. Agoes, Op.cit, hal. 450

${ }^{18}$ Arif Havast Oegroseno, (2014), Archipelagic States: From Concept To Law, The Imli Manual On International Maritime Law, Volume I The Law of the Sea, hal. 132.

19 Susi Pudjiastuti, (2016b), "Surat Badan Reformasi Geospasial No:B-3.4/SESMA/IGD/07/2004 Direktorat Jendral PUM Kementerian Dalam Negeri Republik Indonesia", dalam Pidato Penganugerahan Gelar Doktor Honoris Causa di Bidang Pembangunan Kelautan dan Perikanan, Semarang, Universitas Diponegoro, hal. 4
} 
kemudian menjadi Undang-Undang Nomor 4/Prp Tahun 1960 tentang Perairan Indonesia yang selanjutnya diubah dengan Undang-Undang Nomor 6 Tahun 1996 tentang Perairan Indonesia pada hakikatnya telah merubah cara penetapan laut wilayah sebesar tiga mil laut diukur dari garis air surut atau garis air rendah menjadi laut wilayah selebar 12 mil laut diukur dari garis pangkal lurus yang ditarik dari ujung ke ujung. Dengan demikian garis pangkal lurus tersebut akan melingkari negara Kepulauan Indonesia dimana laut yang terdapat diantara pulau-pulau yang terdapat di dalam garis pangkal lurus tersebut tidak lagi merupakan laut bebas, tetapi telah berubah menjadi perairan kepulauan dan perairan pedalaman yang berada di bawah kedaulatan Indonesia. ${ }^{20}$ Penarikan garis pangkal lurus tersebut merupakan penerapan prinsip Negara Kepulauan yang telah diakui oleh Hukum Internasional melalui Putusan Mahkamah Internasional.

Beberapa pertimbangan yang mendorong Pemerintah Republik Indonesia untuk mengeluarkan pernyataan mengenai wilayah perairan Indonesia adalah :

a. Bahwa bentuk geografis Indonesia yang berwujud negara kepulauan, yang terdiri ribuan pulau-pulau, besar dan kecil yang tersebar di lautan.

b. Demi kesatuan wilayah NKRI, agar semua kepulauan dan perairan (selat) yang ada diantaranya merupakan kesatuan yang utuh, dan tidak dapat dipisahkan antara pulau yang satu dengan lainnya, atau antara pulau dengan perairannya.

c. Bahwa penetapan batas perairan wilayah sebagaimana menurut " Territoriale Zee en Maritieme Kringen Ordonantie 1939" yang dimuat di dalam Staatblad 1939 Nomor 442 sudah tidak cocok lagi dengan kepentingan Indonesia setelah merdeka. Dalam ketentuan tersebut, disebutkan bahwa batas wilayah laut Indonesia hanya selebar 3 mil laut dari garis pantai (coastal baseline) setiap pulau, yaitu perairan yang mengelilingi Kepulauan Indonesia bekas wilayah Hindia Belanda.

d. Bahwa Indonesia setelah berdaulat sebagai suatu negara yang merdeka mempunyai hak sepenuhnya dan berkewajiban untuk mengatur segala sesuatunya, demi untuk keamanan dan keselamatan negara serta bangsanya.

Deklarasi Djuanda pada dasarnya mengedepankan konsep kesatuan wilayah pulau-pulau dan perairan Indonesia dengan menghubungkan titik-titik terluar dari wilayah Indonesia, serta meletakkan kedaulatan seluruh wilayah nusantara. Menurut Mochtar Kusumaatmaja, hanya terdapat satu sarana hukum untuk memenuhi kebutuhan Indonesia dalam memperluas kedaulatannya dan menyatukan wilayah yang semula bercerai berai, yaitu dengan menerapkan prinsip negara kepulauan (archipelago stateprinciple). ${ }^{21}$ Meskipun Konsep negara kepulauan dalam Deklarasi Djuanda pada awalnya tidak berhasil mendapatkan pengakuan internasional dalam Konferensi Hukum Laut Jenewa 1958, namun Indonesia kembali melalukan unilateral action melalui Peraturan Pemerintah Pengganti Undang-Undang Nomor 4 Tahun 1960 tentang Perairan Indonesia yang menegaskan Konsep Negara Kepulauan, sampai akhirnya diplomasi Indonesia diakui dalam UNCLOS 1982.

Pemerintah Indonesia kemudian meratifikasi UNCLOS 1982 melalui UndangUndang Nomor 17 Tahun 1985 yang merupakan salah satu landasan bagi Pemerintah

\footnotetext{
${ }^{20}$ Amiek Soemarmi, Erlyn Indarti, Pujiyono, Amalia Diamantina, (2019), Konsep Negara Kepulauan Dalam Upaya Perlindungan Wilayah Pengelolaan Perikanan Indonesia, Jurnal Masalah-Masalah Hukum, Jilid 48 Nomor 3, hal. 244

${ }^{21}$ Ibid, hal. 245
} 
Indonesia untuk menegakkan kedaulatan wilayah Indonesia sebagai negara kepulauan. Berdasarkan data Kementerian Koordinator Bidang Kemaritiman dan Investasi Indonesia, tercatat hingga Desember 2019 jumlah pulau hasil validasi dan verifikasi Indonesia mencapau 17.491 pulau. Jumlah tersebut telah melampaui target RPJMN 2015-2019 yaitu sejumlah 17.466 pulau. ${ }^{22}$ Jumlah pulau yang telah tervalidasi dan terverifikasi tersebut masih berada pada tingkat data secara nasional dan belum dilaporkan secara resmi ke Perserikatan Bangsa-Bangsa. Adapun pada tahun 2020, proses validasai dan verifikasi terhadap 88 pulau yang tersisa akan dilakukan sehingga jumlah pulau yang masuk dalam wilayah kedaulatan Indonesia dapat diperoleh secara akurat. Diduga, pulau yang dapat berpotensi untuk memenuhi target dalam Undang-Undang Nomor 6 Tahun 1996 tentang Perairan Indonesia yaitu sebanyak 17.504 pulau. $^{23}$

Di antara pulau-pulau tersebut terdapat pulau terluar yang berbatasan langsung dengan negara tetangga dan merupakan bagian terdepan sekaligus menjadi "pagar" wilayah Indonesia. Berdasarkan Keputusan Presiden Nomor 6 Tahun 2017, Presiden Joko Widodo menetapkan sebanyak 111 pulau kecil terluar yang tersebar di 22 Provinsi. Dalam Kepres ini, pulau-pulau kecil terluar disusun dalam daftar yang terdiri dari nama pulau, nama lain pulau, perairan, koordinat titik terluar, titik dasar dan petunjuk jenis garis pangkal, dan provinsi. ${ }^{24}$ Dari 111 pulau kecil terluar, sebanyak 67 diantaranya berbatasan langsung dengan negara tetangga, dan dari 67 pulau tersebut hanya terdapat 28 pulau yang berpenduduk. Tentu saja, keberadaan pulau-pulau terluar tersebut mendapatkan berbagai macam ancaman, tidak hanya dari faktor fenomena alam, melainkan juga ancaman dari negara lain. Ancaman ini bisa saja timbul mengingat masih terdapat sangat banyak pulau yang tidak berpenghuni dan berada di luar kontrol pemerintah.

\section{Perlindungan Pulau-Pulau Terluar di Indonesia}

Wilayah perairan Indonesia yang demikian luas membawa konsekuensi pada tanggungjawab yang besar dalam mengelola dan mengamankannya. Untuk mengamankan laut yang begitu luas, diperlukan kekuatan dan kemampuan dibidang maritim yang besar, kuat dan modern. Ancaman terhadap kedaulatan wilayah Kepulauan Indonesia dewasa ini marak terjadi, dan sebagian besar dikarenakan oleh ancaman yang datang dari negara-negara yang berbatasan dengan wilayah Indonesia, seperti Malaysia, Singapura, Tiongkok dan sebagainya. Hal ini jelas merupakan konsekuensi ketika perlindungan terhadap pulau-pulau terluar belum dilaksanakan secara maksimal.

Dalam perpektif hukum internasional, pengakuan UNCLOS 1982 terhadap Indonesia sebagai negara kepulauan terlihat dalam Pasal 47 ayat (1) UNCLOS 1982 yang menyatakan bahwa An archipelagic State may draw straight archipelagic baselines

22 https://economy.okezone.com/read/2020/02/10/470/2166263/hingga-desember-2019-indonesia-miliki-17491-pulau

23 Ibid

24 Terbitkan Keppres, Jokowi Tetapkan 111 Pulau Kecil Terluar, dalam situs https://nasional.kompas.com/read/2017/03/08/12380111/terbitkan.keppres.jokowi.tetapkan.111.pulau. kecil.terluar?page=all. 
joining the outermost points of the outermost islands and drying reefs of the archipelago provided that within such baselines are included the main islands and an area in which the ratio of the area of the water to the area of the land, including atolls, is between 1 to 1 and 9 to 1. Dengan demikian, perairan Indonesia akan menjadi suatu wilayah yang utuh, di mana batas lautnya diukur dari titik pulau-pulau terluarnya. Hal ini berarti keberadaan pulau-pulau terluar memiliki nilai yang sangat strategis bagi kedaulatan Indonesia karena menjadi dasar pengukuran dan penetapan batas wilayah negara Indonesia dengan negara tetangga.

Dalam konteks regulasi, pada dasarnya telah dibentuk berbagai peraturan perundang-undangan, mulai dari peraturan setingkat Undang-Undang hingga Peraturan Menteri. Undang-Undang Nomor 27 Tahun 2007 tentang Wilayah Pesisir dan Pulau-Pulau Kecil yang kemudian diubah dengan Undang-Undang Nomor 1 Tahun 2014 menjadi landasan perlindungan terhadap pulau-pulau terluar. Salah satu tujuan dari dibentuknya undang-undang ini adalah memberikan kepastian dan perlindungan hukum serta memperbaiki tingkat kemakmuran masyarakat pesisir dan pulau-pulau kecil melalui pembentukan peraturan yang dapat menjamin akses dan hak-hak masyarakat pesisir serta masyarakat yang berkepentingan lain, termasuk pihak pengusaha. Bahkan, secara garis besar undang-undang ini terdiri dari tiga bagian, yaitu perencanaan, pengelolaa, serta pengawasan dan pengendalian.

Pada tingkatan peraturan pelaksanaan, pemerintah membentuk Peraturan Pemerintah Nomor 38 tahun 2002 tentang Daftar Koordinat Geografis Titik-Titik Garis Pangkal Kepulauan Indonesia yang kemudian direvisi dengan Peraturan Pemerintah Nomor 37 Tahun 2008. Peraturan Pemerintah ini merupakan landasan hukum bagi penentuan titik koordinat garis pangkal kepulauan Indonesia. Dalam Pasal 11 Peraturan Pemerintah Nomor 37 Tahun 2008 diatur bahwa Pemerintah melakukan pembaharuan secara rutin untuk memperbaiki dan melengkapi kekurangan-kekurangan dalam penetapan koordinat geografis titik-titik terluar untuk menarik garis pangkal kepulauan. Pembaharuan tersebut dilaksanakan oleh instansi pemerintah yang menyelenggarakan tugas di bidang survey dan pemetaan, di bawah koordinasi kementerian yang membidangi politik, hukum dan keamanan. Pentingnya dilakukan pembaharuan adalah mengingat kemungkingan terjadinya perubahan, baik secara alami seperti munculnya pulua-pulau baru, atol, karang kering terluar, elevasi surut terluar, muara sungai dan terusan, dan juga terdapatnya pelabuhan yang dapat digunakan untuk penetapan titik-titik terluar dari garis pangkal kepulauan.

Meskipun telah dibentuk dasar hukum penentuan titik koodinat garis pangkal kepulauan, namun bentuk perlindungan terhadap pulau-pulau terluar tidak hanya dari perspektif penentuan titik garis pangkal kepulauan, melainkan melalui upaya pemanfaatan dan pengelolaan pulau-pulau terluar tersebut. Dalam hal ini, pemerintah juga telah membentuk Peraturan Pemerintah Nomor 62 Tahun 2010 
tentang Pemanfaatan Pulau-Pulau Kecil Terluar, dan Peraturan Presiden Nomor 78 Tahun 2005 tentang Pengelolaan Pulau-Pulau Kecil Terluar. Berdasarkan Pasal 1 angka 2 PP Nomor 62 Tahun 2010, pulau-pulau kecil terluar merupakan pulau-pulau kecil yang memiliki titik-titik dasar koordinat geografis yang menghubungkan garis pangkal laut kepulauan sesuai dengan hukum internasional dan nasional. Sedangkan pemanfaatan pulau-pulau kecil terluar merupakan kegiatan yang berkaitan dengan upaya memanfaatkan potensi sumber daya pulau-pulau kecil terluar dan perairan di sekitarmya sampai paling jauh 12 (dua belas) mil laut diukur dari garis pantai dalam upaya menjaga kedaulatan Negara Kesatuan Republik Indonesia. Dengan demikian berdasarkan hukum internasional, wilayah laut teritorial yang merupakan wilayah kedaulatan Indonesia yaitu paling jauh 12 mil laut dari garis pantai pulau terluar tersebut.

Dalam Peraturan Presiden Nomor 78 Tahun 2005 disebutkan bahwa pengelolaan pulau-pulau kecil terluar adalah rangkaian kegiatan yang dilakukan secara terpadu untuk memanfaatkan dan mengembangkan potensi sumber daya pulau-pulau kecil terluar dari wilayah Republik Indonesia untuk menjaga keutuhan Negara Kesatuan Republik Indonesia. Perlindungan dan pengelolaan pulau-pulau terluar dilakukan dengan tujuan, yaitu :

a. Menjaga keutuhan Negara Kesatuan Republik Indonesia, keamanan nasional, pertahanan negara, dan menciptakan stabilitas kawasan.

b. pemanfaatan sumber daya alam dalam rangka pembangunan berkelanjutan.

c. Memberdayakan masyarakat dalam rangka meningkatkan kesejahteraannya.

Sebagai peraturan pelaksana, Perpres Nomor 78 Tahun 2005 ini mengamanatkan pembentukan tim koordinasi dengan tugas mengkoordinasikan dan merekomendasikan penetapan rencana dan pelaksanaan pengelolaan pulau-pulau kecil terluar serta melakukan monitoring dan evaluasi pelaksanaan pulau-pulau kecil terluar. Dalam hal pengorganisasian pengelolaan pulau kecil terluar, dan untuk menghindari tumpang tindih kewenangan, ditetapkan dua tim kerja. Tim kerja I membidangi sumberdaya alam, lingkungan hidup, infrastruktur dan perhubungan, ekonomi, sosial, dan budaya. Sedangkan tim kerja II membidangi wilayah, pertahanan, dan keamanan. ${ }^{25}$

Pada dasarnya, pengelolaan pulau-pulau terluar dapat dilihat dari dua aspek, yaitu aspek pengelolaan itu sendiri, dan aspek pemberdayaan masyarakat. Aspek pengelolaan dilihat dari pengembangan dan pembangunan fisik, baik mempertahankan eksistensi pulau-pulau terluar maupun pembangunan infrastrukturnya. Adapun dari segi pemberdayaan akan dilihat dari aspek pembangunan sosial ekonomi kemasyarakatan. ${ }^{26}$ Menjadi pelajaran berharga

\footnotetext{
25 Deddy Theohery, (2018), Pengelolaan Pulau-Pulau Kecil Terluar Indonesia Dalam Perpekstif Hukum Laut Internasional, Jurnal Ilmu Hukum Alethea, v2n1, hal. 27

${ }^{26}$ Fadjri Alihar, Op.cit. hal. 46
} 
lepasnya pulau Sipadan dan Ligitan dari Indonesia merupakan bentuk kelalaian atas pengelolaan pulau-pulau terluar, tidak hanya karena aspek pengelolaan melainkan juga aspek pemberdayaan masyarakat. Jarak antara pulau-pulau terluar dengan ibukota Provinsi maupun Kabupaten/Kota yang sangat jauh, mengakibatkan pulaupulau terluar menjadi tidak tersentuh, baik dalam hal pembagunan maupun pemberdayaan masyarakat.

Terkait dengan pengelolaan dan pemberdayaan masyarakat di pulau-pulau terluar, pada dasarnya tidak hanya menjadi tanggun jawab pemerintah pusat, melainkan juga pemerintah daerah. Undang-Undang Nomor 23 Tahun 2014 tentang Pemerintahan Daerah telah memberikan kewenangan kepada pemerintah daerah untuk mengurus daerahnya masing-masing berdasarkan prinsip otonomi daerah. Dalam hal ini, Pemerintahan Daerah berkewajiban untuk mampu mengelola dan memanfaatkan serta mengawasi setiap ruang yang ada di daerahnya, termasuk pulua-pulau terluar yang masuk dalam wilayah administrasi daerah yang bersangkutan.

\section{Penutup}

Konsep negara kepulauan dalam fakta telah menjadi hukum internasional secara umum, namun dalam tataran implementasi eksistensi kedaulatan negara kepulauan tetap harus terus diperjuangkan oleh Indonesia sebagai negara kepulauan. Dalam hal ini, perjuangan tersebut terkait dengan perlindungan terhadap keberadaan pulau-pulau terluar yang sekaligus menjadi batas antara Indonesia dengan negaranegara tetangga sekaligus menegaskan kedaulatan Indonesia. Sebagai negara kepulauan, Indonesia menghadapi berbagai persoalan dan ancaman yang berkaitan dengan keutuhan wilayahnya, terutama bagian pulau-pulau terluar. Upaya perlindungan yang dilakukan sampai saat ini adalah melalui berbagai regulasi, mulai dari tingkat undang-undang, hingga pada peraturan pelaksana baik berupa Peraturan Presiden maupun Peraturan Menteri. Pembentukan regulasi ini tidak membawa dampak yang signifikan terhadap perlindungan pulau-pulau terluar tanpa disertai dengan upaya dan tindakan pemanfaatan dan pengelolaan pulau-pulau terluar tersebut. Pemanfaatan dan pengelolaan pulau-pulau terluar tersebut tidak hanya menjadi tanggung jawab Pemerintah Pusat, melainkan juga Pemerintah Daerah yang telah diberikan kewenangan untuk mengurus wilayah otonomnya. Keterlibatan Pemerintah Daerah ini selain merupakan bentuk pelaksanaan kewenangan, juga dikarenakan Pemerintah Daerah yang lebih banyak mengetahui kebutuhan pengelolaan dan pemberdayaan masyarakat yang ada di pulau-pulau terluar.

\section{REFERENSI}

Amiek Soemarmi, Erlyn Indarti, Pujiyono, Amalia Diamantina, (2019), Konsep Negara Kepulauan Dalam Upaya Perlindungan Wilayah Pengelolaan Perikanan Indonesia, Jurnal Masalah-Masalah Hukum, Jilid 48 Nomor 3. 
Ayub Torri Satriyo Kusumo, (2010), Optimalisasi Pengelolaan dan Pemberdayaan PulauPulau Terluar Dalam Rangka Mempertahankan Keutuhan Negara Kesatuan Republik Indonesia, Jurnal Dinamika Hukum, v10n3.

Bambang Susanto, (2004), Kajian Yuridis Permasalahan Batas Maritim Wilayah Laut Republik Indonesia (Suatu Pandangan TNI AL Bagi Pengamanan Batas Wilayah Laut RI), Indonesian Journal of International Law, Special Edition, Desember.

Deddy Theohery, (2018), Pengelolaan Pulau-Pulau Kecil Terluar Indonesia Dalam Perpekstif Hukum Laut Internasional, Jurnal Ilmu Hukum Alethea, v2n1.

Etty. R. Agoes, (2004), Praktik Negara-Negara Atas Konsepsi Negara Kepulauan, Jurnal Hukum Internasional, v1n3.

F. Sugeng Istanto, (1994), Hukum Internasional, Yogyakarta: Penerbitan Universitas Atma Jaya.

Fadjri Alihar, (2018), Kebijakan Pengelolaan Pulau-Pulau Terluar Ditinjau Dari Aspek Kependudukan, Jurnal Kebijakan Sosial Ekonomi Kelautan dan Perikanan, v8n1.

I Wayan Parthiana, (1990), Pengantar Hukum Internasional, Bandung: Mandar Maju.

Jawahir Thontowi dan Pranoto Iskandar, (2006), Hukum Internasional Kontemporer, Bandung: PT.Refika Aditama.

Mochtar Kusumaatmadja dan Agoes, E. R. (2010). Pengantar Hukum Internasional. Bandung: PT. Alumni.

Rebecca M. Wallace, (1993), Hukum Internasional, Semarang: IKIP Semarang Press.

Sigit Sutadi Nugroho, (2019), Implementasi Ketentuan Pasal 50 UNCLOS di Wilayah Negara Kepulauan, Junal Rechtsvinding, v8n2.

Maskun, Konsepsi Negara Kepulauan, dalam www.negarahukum.com

https://id.wikipedia.org/wiki/Indonesia\#Geografi

https:/ / economy.okezone.com/read/2020/02/10/470/2166263/hingga-desember2019-indonesia-miliki-17-491-pulau

https://nasional.kompas.com/read/2017/03/08/12380111/terbitkan.keppres.joko wi.tetapkan.111.pulau.kecil.terluar?page=all. 